\title{
KONDISI CURAH HUJAN PADA KEJADIAN BANJIR JAKARTA DAN ANALISIS KONDISI UDARA ATAS WILAYAH JAKARTA BULAN JANUARI - FEBRUARI 2013
}

\author{
M. Djazim Syaifullah ${ }^{2)}$
}

\begin{abstract}
Intisari
Kondisi curah hujan di wilayah Jakarta pada kejadian banjir besar tanggal 17 Januari 2013 telah dianalisis yang dihubungkan dengan kondisi atmosfer pada selang waktu tersebut. Data curah hujan menggunakan data TRMM sedangkan analisis kondisi atmosfer menggunakan data rawinsonde. Hasil analisis menunjukkan bahwa puncak kejadian banjir Jakarta musim hujan tahun 2013 terjadi pada tanggal 17 Januari 2013 disebabkan oleh faktor lokal yang sangat kuat ditambah dengan faktor global yang mendukung, sementara pada kejadian banjir tanggal 6 Februari 2013 faktor lokalnya tidak begitu kuat sehingga diduga faktor globalnya lebih dominan. Untuk wilayah Jakarta terdapat indikasi bahwa pada musim hujan, intensitas curah hujan wilayah Jakarta yang melebihi $40 \mathrm{~mm} /$ hari selama lebih dari empat hari berturut-turut mempunyai potensi besar menimbulkan genangan (banjir). Perlunya kewaspadaan yang lebih tinggi lagi dengan meningkatkan antisipasi pada saat terjadi curah hujan dengan intensitas tinggi selama empat hari berturut-turut.
\end{abstract}

\begin{abstract}
Rainfall condition in the Jakarta area on great flood January 17, 2013 has been analyzed that is associated with the atmospheric conditions. Rainfall Data using Tropical Rainfall Measuring Mission TRMM data and analysis of the atmospheric conditions using rawindsonde data. Results of analysis showed that the peak of the flooding incident, Jakarta's wet season 2013 occurred on January 17, 2013 is caused by a very strong local factors coupled with the global factors, while the flood February 6, 2013 global factors are thought to be more dominant than local factors. For the Jakarta area there are indications that in the rainy season, the intensity of the precipitation area of Jakarta that exceeds 40 $\mathrm{mm} /$ day for more than four consecutive days have great potential cause inundation (flooding). The need for vigilance is higher with increasing anticipation when the rainfall with high intensity for four consecutive days.
\end{abstract}

Kata kunci : TRMM, Radiosonde, banjir

\section{PENDAHULUAN}

Musibah banjir besar pada bulan Januari khususnya tanggal 17 Januari 2013 telah hampir melumpuhkan Daerah Khusus Ibukota (DKI) Jakarta. Sebagian besar kawasan ibukota terendam banjir dalam waktu yang relatif lama. Beberapa tanggul di wilayah sungai maupun kanal jebol tidak kuat menahan besarnya debit air sehingga menambah luasnya genangan di wilayah Jakarta. Wilayah yang memiliki daya dukung lingkungan lemah, menjadi semakin parah akibat banjir ini. Kawasan Bundaran Hotel Indonesia di jantung Jakarta serta Istana Negara pun tidak luput dari kepungan banjir. Dalam sekejap, status
Jakarta darurat banjir segera diberlakukan hingga sepuluh hari ke depan.

Banjir tersebut diperkirakan telah menyebabkan kerugian mencapai Rp 20 Triliun (Antaranews, 2013). Sementara kerugian ekonomi lebih dari satu triliun rupiah. Badan Nasional Penanggulangan Bencana (BNPB) menyatakan jumlah resmi korban yang tercatat selama banjir Jakarta 2013 adalah 20 korban jiwa, dan 33.502 orang terpaksa mengungsi. Selain sistem drainase yang buruk, dan jebolnya berbagai tanggul di wilayah Jakarta, kondisi curah hujan yang tinggi sejak Desember 2012 menyebabkan meningkatnya volume 13 sungai yang melintasi Jakarta. Hingga pertengahan Januari 2013,

\footnotetext{
2) Peneliti Madya UPT Hujan Buatan BPPT, djazimsy@yahoo.com
} 
Jakarta tercatat mencapai rekor curah hujan hingga 250-300 mm, melebihi kondisi Banjir Jakarta 2002 yang mencapai $200 \mathrm{~mm}$,

Setelah bencana banjir surut pun masih menyisakan masalah kesehatan diantaranya munculnya beberapa macam penyakit gatal-gatal, demam, hipertensi, rematik, penyakit kulit dan radang tenggorokan serta infeksi saluran pernafasan atas (ISPA).

Selain faktor permukaan tanah (tata guna lahan, sistem drainase, daya serap tanah) banjir terjadi akibat curah hujan dengan intensitas tingga dalam waktu yang relatif lama. Dalam pengamatan Badan Meteorologi, Klimatologi dan Geofisika (BMKG) kejadian hujan lebat pada tanggal 17 Januari 2013 di luar prediksi, fenomena tersebut terjadi lokal di wilayah Jabodetabek, sementara wilayah lain seperti di Sumatera dan Jawa Tengah hingga Jawa Timur secara umum tidak banyak pertumbuhan awan. Memang diperkirakan ada beberapa indikator cuaca yang menyebabkan kondisi ekstrim tersebut, salah satunya monsoon tetapi faktor lokal diperkirakan lebih dominan.

Upaya untuk menekan kerugian baik materiil maupun non materiil harus dilakukan mengingat kejadian banjir di wilayah Jakarta ini selalu mengalami perulangan setiap tahunnya. Apabila bisa lebih dipahami fenomena cuaca yang menyebabkan kejadian ekstrim secara lebih dini maka upaya antisipasi akan memberikan hasil yang lebih efektif.

Tulisan ini mengkaji kondisi curah hujan dan kondisi cuaca selama bulan Januari sampai Februari 2013 khususnya pada saat kejadian banjir tanggal 17 Januari 2013 dan 6 Februari 2013 serta membandingkan fenomena banjir keduanya secara meteorologis. Disamping itu juga akan dilakukan analisis karasteristik atmosfer pada dua kejadian banjir tersebut.

\section{DATA DAN METODE}

\section{$2.1 \quad$ (Tropical Rainfall Measuring Mission) TRMM}

Data TRMM adalah data precipitasi (curah hujan) yang didapat dari satelit meteorologi TRMM dengan sensornya PR (Precipitation Radar), TMI (TRMM Microwave Imager), dan VIRS (Visible and Infrared Scanner), CERES (Clouds and the Earth's Radiant Energy System), dan LIS (Lightning Imaging Sensor). Satelit TRMM tersebut merupakan hasil kerjasama dua badan antariksa nasional, yaitu Amerika Serikat NASA (National Aeronautics and Space Administration) dan Jepang NASDA (National Space Development of Japan), sekarang berubah menjadi JAXA : (Japan Aerospace Exploration Agency). Satelit TRMM diluncurkan pada tanggal 27 November 1997 pada jam 6:27 pagi waktu
Jepang dan dibawa oleh roket $\mathrm{H}$-II di pusat stasiun peluncuran roket milik JAXA di TanegashimaJepang, berorbit polar (non-sunsynchronous) dengan inklinasi sebesar $35^{\circ}$ terhadap ekuator, berada pada ketinggian orbit $350 \mathrm{~km}$ (pada saatsaat awal diluncurkan), dan diubah ketinggian orbitnya menjadi 403 km sejak 24 Agustus 2001 sampai sekarang, seperti terlihat pada Gambar 1. Pengoperasian satelit TRMM pada ketinggian orbit $403 \mathrm{~km}$ ini dikenal dengan istilah TRMM boost.

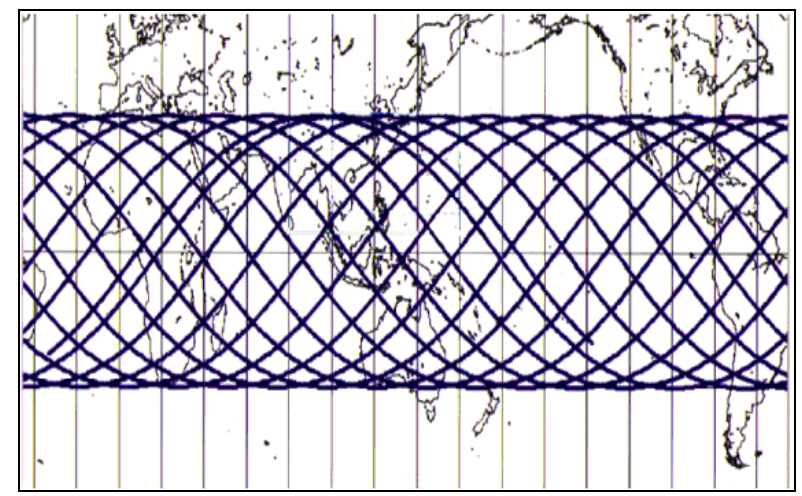

Gambar 1. Orbit satelit TRMM

Karakteristik umum sensor-sensor satelit TRMM dapat diungkapkan sebagai berikut. Pertama, sensor VIRS (Visible Infrared Scanner) terdiri dari 5 kanal, masing-masing pada panjang gelombang 0,$63 ; 1,6 ; 3,75,10,8$ dan $12 \mu \mathrm{m}$. Sensor VIRS ini terutama digunakan untuk pemantauan liputan awan, jenis awan dan temperatur puncak awan, dan sensor VIRS TRMM ini memiliki kemiripan dengan sensor AVHRR NOAA (Advance Very High Resolution Radiometer, National Oceanic and Atmospheric Administration). Resolusi spasial dari data yang dihasilkan oleh sensor VIRS ini adalah 2,2 km. Kedua, sensor TMI (TRMM Microwave Imager) merupakan suatu multichannel passive microwave radiometer yang beroperasi pada 5 frekuensi yaitu 10,65; 19,35; 37,0; dan 85,5 GHz polarisasi ganda dan pada $22,235 \mathrm{GHz}$ polarisasi tunggal. Dari sensor TMI ini dapat diekstraksi data untuk integrated column precipitation content, air cair dalam awan (cloud liquid water), es awan (cloud ice), intensitas hujan (rain intensity), tipe hujan (rain type) misalnya hujan stratiform ataukah hujan konvektif.

Sensor TMI ini memiliki kemiripan dengan sensor SSM/I DMSP (Special Sensor Microwave / Imager, Defense Meteorological Satellite Program). Sensor ke tiga adalah sensor PR (Precipitation Radar). Sensor PR ini merupakan sensor radar untuk pemantauan presipitasi yang pertama di antariksa. Sensor PR ini bekerja pada frekuensi 13,8 GHz untuk mengukur distribusi presipitasi secara 3 dimensi, baik untuk presipitasi di atas daratan maupun di atas lautan; serta untuk menentukan kedalaman lapisan presipitasi. 
Pada hasil akhirnya nanti, beberapa data dari hasil analisis beberapa satelit meteorologi digabungkan / dikombinasikan untuk memproduski data hujan (presipitasi) yang disebut dengan produk TRMM Multisatellite Precipitation Analysis (TMPA) yang memiliki tingkat keakurasian data lebih baik dari data-data aslinya.

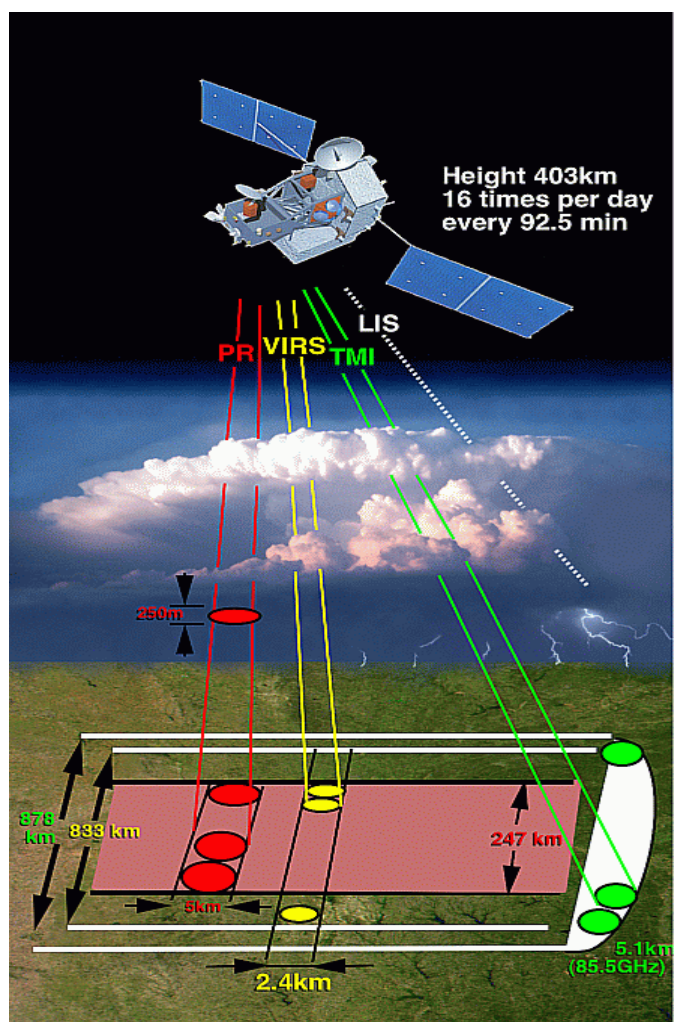

Gambar 2. Instrumentasi Satelit TRMM (sumber : http://trmm.gsfc.nasa.gov/)

Produk terakhir dari JAXA berupa Global Rainfall Map in Near-Real-Time (GSMaP_NRT) yang tersedia empat jam setelah pengamatan dengan resolusi temporal setiap jam dan resolusi spasial $0.1^{\circ}$ geografis. Sistem ini didasarkan pada kombinasi algoritma MW-IR yang memakai TRMM TMI, Aqua AMSR-E, DMSP SSM/I dan SSMIS, NOAA-19 AMSU dan MetOp-A AMSU, dan GEO IR yang dikembangkan oleh proyek GSMaP (Global Satellite Mapping of Precipitation). Data format binary telah tersedia secara archieve dan bias diunduh dengan fasilitas file transfer protocol (ftp) di : ftp://hokusai.eorc.jaxa.jp/realtime/archive/. Format data terkompres dan untuk mengolahnya perlu diekstrak filenya.

\subsection{Radiosonde Stasiun Cengkareng}

Data radiosonde yang dipakai adalah data pengukuran sounding stasiun Cengkareng Jakarta bulan Januari sampai Februari 2010. Data peluncuran radiosonde secara lengkap dapat diunduh di situs : http://weather.uwyo.edu/ upperair/sounding.html. Format data dalam bentuk
ASCII yang dapat langsung dilihat isi filenya sehingga dapat diproses dengan mudah.

Ada beberapa parameter data rawinsonde yang digunakan untuk analisis dan prediksi pertumbuhan awan konvektif. Pada dasarnya parameter tersebut mengarah pada : parameter moisture (kandungan massa uap air yang ada di atmosfer), parameter kelabilan (sebagai sarana atau media untuk terjadinya konvektivitas di atmosfer) dan parameter kelembaban (sebagai pendukung dari moisture yang ada untuk terjadi pembentukan awan) serta parameter angin (sebagai supplay massa uap air dari luar atau sebagai mass transport). Dari parameter tersebut muncul beberapa Indeks untuk menggambarkan / menduga kondisi udara pada saat terukur.Sebelum menujuk ke analisis indeks rawinsonde perlu dianalisis parameter rawinsonde yang lain sebagai pembanding dalam studi kasus ini. Parameter tersebut adalah parameter moisture yang disebut Mixing Ratio (MR) dan Precipitable water (PW).

Mixing Ratio : adalah perbandingan massa uap air $m_{v}$ dengan massa udara kering $m_{d}$ yang terdapat dalam satu volume tertentu, dapat

$$
M R \equiv \frac{m_{v}}{m_{d}}
$$

diekspresikan dalam bentuk :(Roger, 1979).

Mixing ratio umumnya dinyatakan dalam $\mathrm{g} / \mathrm{kg}$ udara kering. Di atmosfer lintang tengah besarnya MR umumnya beberapa $\mathrm{g} / \mathrm{kg}$, sementara di daerah tropis mencapai 10 sampai $16 \mathrm{~g} / \mathrm{kg}$, pada kondisi udara basah bahkan mencapai $20 \mathrm{~g} / \mathrm{kg}$. Dengan mengetahui mixing ratio pada suatu daerah tertentu kita dapat melihat kebasahan udara / kandungan massa uap air, sehingga potensi untuk terbentuknya awan konvektif dapat diprakirakan.

Pada pengukuran rawinsonde perhitungan MR dilakukan dengan pendekatan empiris sebagai fungsi dari profil tekanan (dalam milibar) dan profil suhu (dalam ${ }^{\circ} \mathrm{C}$ ) karena yang terukur adalah data tekanan dan suhu (bukan mengukur kandungan uap air). Persamaan empiris tersebut adalah

(Glickman, 2000) :

$$
M R=\frac{0.622 \cdot p}{p-e}
$$

dengan :

p : tekanan udara lingkungan (dalam milibar)

$e$ : tekanan uap air jenuh (vapor pressure)

Precipitable water (PW) : didefinisikan sebagai ekivalen dari jumlah air di kolom udara (yang diekspresikan oleh nilai MR) apabila semua uap air pada kolom udara tersebut mengembun. 
Proses pengembunan tersebut dipengaruhi oleh perbandingan densitas air dan densitas udara $\left(\rho_{\mathrm{w}} / \rho_{\mathrm{a}}\right)$ juga oleh tekanan masing-masing kolom udara tersebut. Perhitungan PW dilakukan dengan mengintegrasikan uap air yang ada pada kolom udara dari permukaan (surface) sampai level ketinggian tertentu (biasanya sampai 500 mbar $\approx$ 18000 kaki). PW secara empiris dihitung dengan persamaan : (Glickman, 2000)

$$
P W=0.0004 \int_{p 0}^{p z} q \cdot d p
$$

dimana :

$$
\begin{aligned}
& \text { PW : Precipitable Water (dalam inch) } \\
& q \text { : perbandingan densitas air } \\
& \text { dengan densitas udara }\left(\rho_{w} / \rho_{a}\right) \text {. }
\end{aligned}
$$

Nilai PW menggambarkan potensi uap air yang dapat menjadi awan-awan potensial.

Convective Available potential Energy (CAPE), dalam meteorologi memberikan pengertian jumlah energy dari suatu parsel udara yang harus dimiliki supaya terangkat secara adiabat di atmosfer. Secara efektif CAPE merupakan energi apung dan merupakan indikator ketidakstabilan atmosfer. Ketika massa udara tidak stabil, kandungan massa udara yang diangkat naik ke atas dipercepat oleh perbedaan tekanan antara lapisan udara di bawah dengan lapisan yang lebih tinggi, hal ini biasanya akan menciptakan awan vertikal konvektif. Namun jika tidak ada uap air yang cukup maka tidak ada kemampuan untuk kondensasi, sehingga badai, awan, dan hujan tidak akan terbentuk. Sedangkan CIN(Convective Inhibition) adalah anti-CAPE (CAPE negatif) di lapisan troposfer bawah. Ini adalah kondisi parcel udara yang terangkat ke boundary layer akan turun kembali. Semakin tebal lapisan CIN maka akan semakin sulit pengangkatan secara konvektif.

Lifted Indek (LI). Ada beberapa macam indeks dalam analisa udara atas yang berguna untuk melihat kelabilan udara, peluang pertumbuhan awan konvektif, peluang terbentuknya badai (thunderstorm) dan lain-lain. Salah satu indek yang cukup penting diantaranya adalah Lifted Indek (LI). Indeks ini digunakan secara umum untuk menentukan tingkat stabilitas atmosfer. Lifted indeks merupakan modifikasi dari Showalter indeks yang biasanya banyak dipakai untuk melihat kelabilan dalam kondisi konvektif frontal (frontal convective weather). Nilai LI dihitung dengan mengangkat parsel udara dari level dekat permukaan (setebal $50 \mathrm{mb}$ dari permukaan / sekitar 30 feet) sampai dengan level $500 \mathrm{mb}$ secara adiabatik. Selisih suhu parsel tersebut dengan suhu lingkungannya pada level $500 \mathrm{mb}$ disebut dengan LI. Nilai LI mempunyai batas ambang untuk menduga potensi thunderstorm seperti terlihat pada Tabel 1.

Tabel 1. Nilai ambang untuk penduga potensi Thunderstorm beberapa indek radiosonde

\begin{tabular}{|c|c|c|c|}
\hline \multirow{2}{*}{ Indek } & \multicolumn{3}{|c|}{ Potential Thunderstorm } \\
\cline { 2 - 4 } & Weak & Moderate & Strong \\
\hline Lifted & $>-3$ & $-3 \sim-5$ & $<-5$ \\
\hline
\end{tabular}

sumber: Universal RAwinsonde OBservation (RAOB)

\subsection{Profil Angin}

Profil angin atas memberikan informasi transport massa udara dari suatu daerah tekanan tinggi ke daerah yang bertekanan rendah, sehingga dengan melihat arah angin secara vertikal dapat diketahui dari mana supply massa udara yang masuk ke daerah target sampai pada paras tertentu. Hasil pengolahan arah dan kecepatan angin diperoleh komponen zonal (arah barat - timur) dan komponen meridional (arah utara - selatan). Untuk wilayah Jakarta komponen zonal positif (baratan) merepresentasikan angin yang membawa udara basah (monsoon asia) sedangkan komponen zonal negative (timuran) merepresentasikan angin membawa massa udara kering (monsoon Australia).

\section{HASIL}

Hasil analisis meliputi analisis kejadian hujan baik secara temporal maupun analisis spasial dan analisis kondisi atmosfer dari nilai indek dan parameter radiosonde serta analisis kondisi angin atas.

\subsection{Kondisi Curah Hujan Wilayah Jakarta}

Kondisi curah hujan selama bulan januari sampai dengan Februari 2013 didapat dari data TRMM Jaxa yang tersedia empat jam setelah pengamatan dengan resolusi temporal setiap jam dan resolusi spasial $0.1^{\circ}$ geografis. Secara grafik terdapat pada Gambar 3. yang memperlihatkan kondisi curah hujan wilayah DKI Jakarta dalam bulan Januari - Februari 2013. 


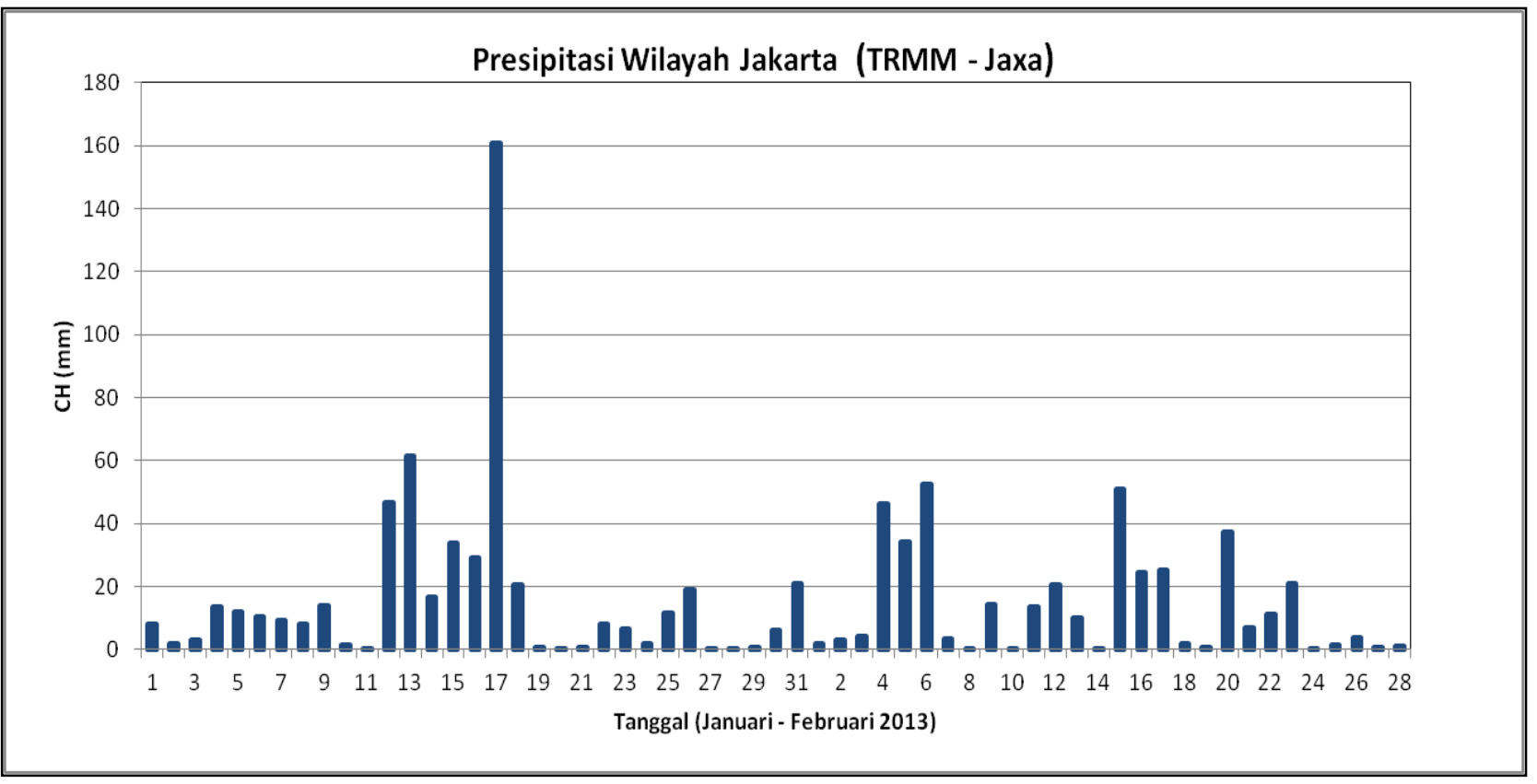

Gambar 3. kondisi curah hujan wilayah DKI Jakarta dalam bulan Januari - Februari 2013

Wilayah DKI Jakarta sejak tanggal 12 Januari 2013 sampai dengan tanggal 18 Januari 2013 mendapatkan curah hujan rerata yang relatif tinggi (rerata > $30 \mathrm{~mm} /$ hari) yang jauh melebihi daya tampung / daya serap permukaan tanah yang sebagian besar sudah mengalami perubahan lahan. Setelah terakumulasi selama satu minggu dan daya serap tanah sudah mencapai titik jenuh, maka curah hujan yang jatuh langsung berubah menjadi aliran dan genangan. Demikian juga kondisi banjir tanggal 6 Februari merupakan hasil akumulasi curah hujan sejak tanggal 4 Februari 2013, sehingga dapat disimpulkan bahwa curah hujan wilayah Jakarta lebih dari empat hari berturut-turut di atas $40 \mathrm{~mm} /$ hari dalam musim hujan mempunyai potensi besar menimbulkan genangan (banjir).

Untuk melihat sebaran curah hujan di wilayah DKI Jakarta pada kejadian banjir dibuat analisis spasial curah hujan seperti terlihat pada Gambar 4 (tanggal 17 Januari 2013) dan Gambar 5 (tanggal 6 Februari 2013). Gambar 4 dan Gambar 5 adalah hasil pengolahan data presipitasi TRMM dari Jaxa yang diolah dengan perangkat lunak Grid Analysis and Display System (GrADS).

Dari Gambar 4, terlihat bahwa pada tanggal 17 Januari 2013 sebagian besar wilayah Jakarta mempunyai curah hujan di atas $120 \mathrm{~mm}$ dan bahkan mencapai $160 \mathrm{~mm}$ dalam satu hari. Curah hujan dengan intensitas sebesar ini termasuk kategori hujan lebat. Dari gambar juga terlihat bahwa curah hujan pada tanggal tersebut hanya terkonsentrasi di wilayah Jakarta, Banten dan bagian barat Jawa Barat.

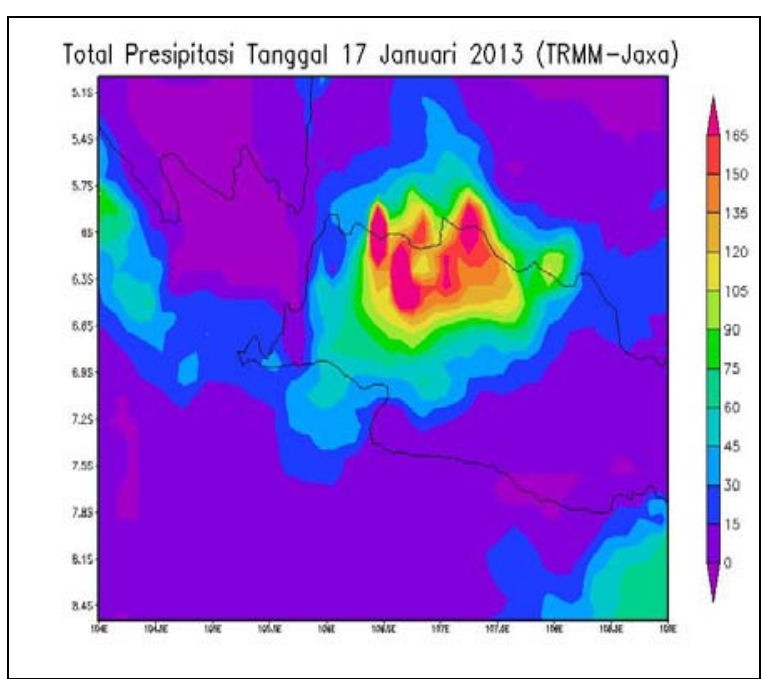

Gambar 4. Sebaran curah Hujan tanggal 17 Januari 2013

Kejadian hujan pada tanggal 6 Februari 2013 seperti terlihat pada Gambar 5, yang menunjukkan besarnya curah hujan wilayah Jakarta pada tanggal tersebut mencapai $60 \sim 70 \mathrm{~mm} /$ hari

Dilihat dari intensitasnya, pada tanggal 5 Februari 2013 total presipitasi lebih kecil dibandingkan pada kejadian banjir 17 Januari 2013, tetapi karena kondisi permukaan tanah yang sudah sangat jenuh maka besarnya curah hujan tersebut masih menyebabkan terjadinya genangan banjir di sebagian wilayah Jakarta. 


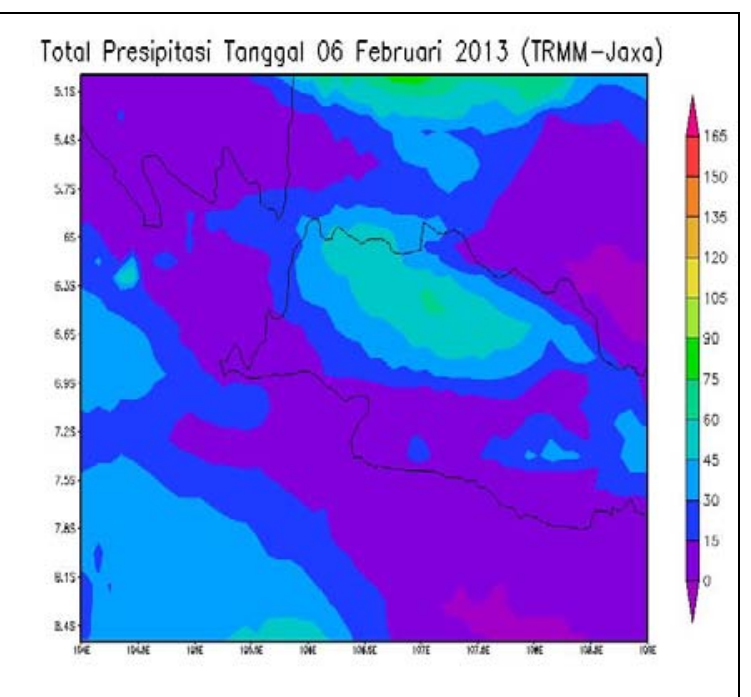

Gambar 5. Sebaran curah Hujan tanggal 06 Februari 2013

\subsection{Indek dan Parameter Radiosonde}

Indeks radiosonde yang dianalisis adalah Lifted indeks sedangkan parameter radiosonde yang dianalisis adalah Mixing Ratio (MixR) dan
Precipitable Water (PW) serta Convective Available Potential Energy (CAPE).

Mixing Ratio dan Precipitable Water. Dari hasil analisis radiosonde nilai Precipitable Water (PW) dan nilai Mixing Ratio (MixR) seperti terlihat pada Gambar 6.

Dari Gambar 7 terlihat bahwa bahwa secara umum baik nilai MixR dan PW pada kejadian banjir tanggal 17 Januari 2013 lebih tinggi dibandingkan dengan kejadian banjir tanggal 6 Februari 2013. Nilai MixR pada kejadian pertama mencapai 18 $\mathrm{g} / \mathrm{Kg}$ sedangkan pada kejadian kedua berkisar antara $16.5 \sim 17 \mathrm{~g} / \mathrm{Kg}$. Nilai PW pada kejadian pertama mencapai $60 \mathrm{~mm}$ sedangkan pada kejadian kedua sekitar $55 \mathrm{~mm}$. Hal ini menunjukkan bahwa potensi uap air di atmosfer pada kejadian banjir tanggal 17 Januari 2013 lebih besar dibandingkan pada kejadian banjir tanggal 6 Februari 2013. Apabila potensi uap air yang besar ini didukung oleh energi pengangkatan yang besar pula, maka peluang pertumbuhan awan-awan konvektif sampai terbentuknya awan Cumulonimbus $(\mathrm{Cu})$ juga besar.

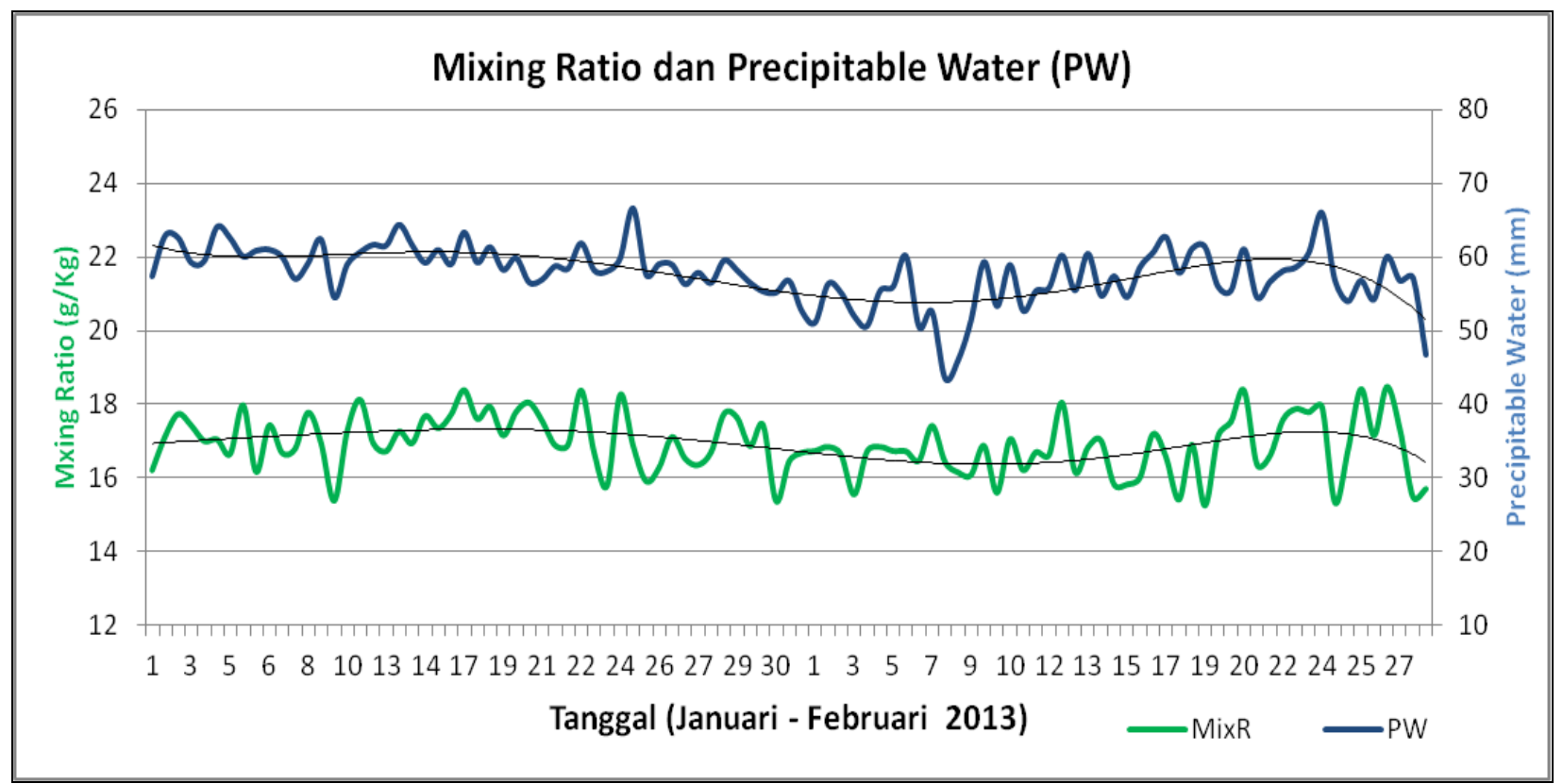

Gambar 6. Mixing Ratio dan Precipitable Water

Lifted Indeks. Hasil analisis Lifted indeks bahwa seperti terlihat pada Gambar 7 menunjukkan pada bulan Januari - Februari 2013 secara umum mempunyai nilai negatif yang mengindikasikan kondisi udara yang labil sehingga mempunyai peluang pertumbuhan awan konvektif dan terbentuknya badai (thunderstorm). Pada hari-hari kejadian banjir tanggal 17 Januari 2013 nilai LI konsisten negatif yang berarti pada periode tersebut kondisi lokal sangat dominan ditandai dengan konvektivitas dan labilitas atmosfer yang tinggi. 


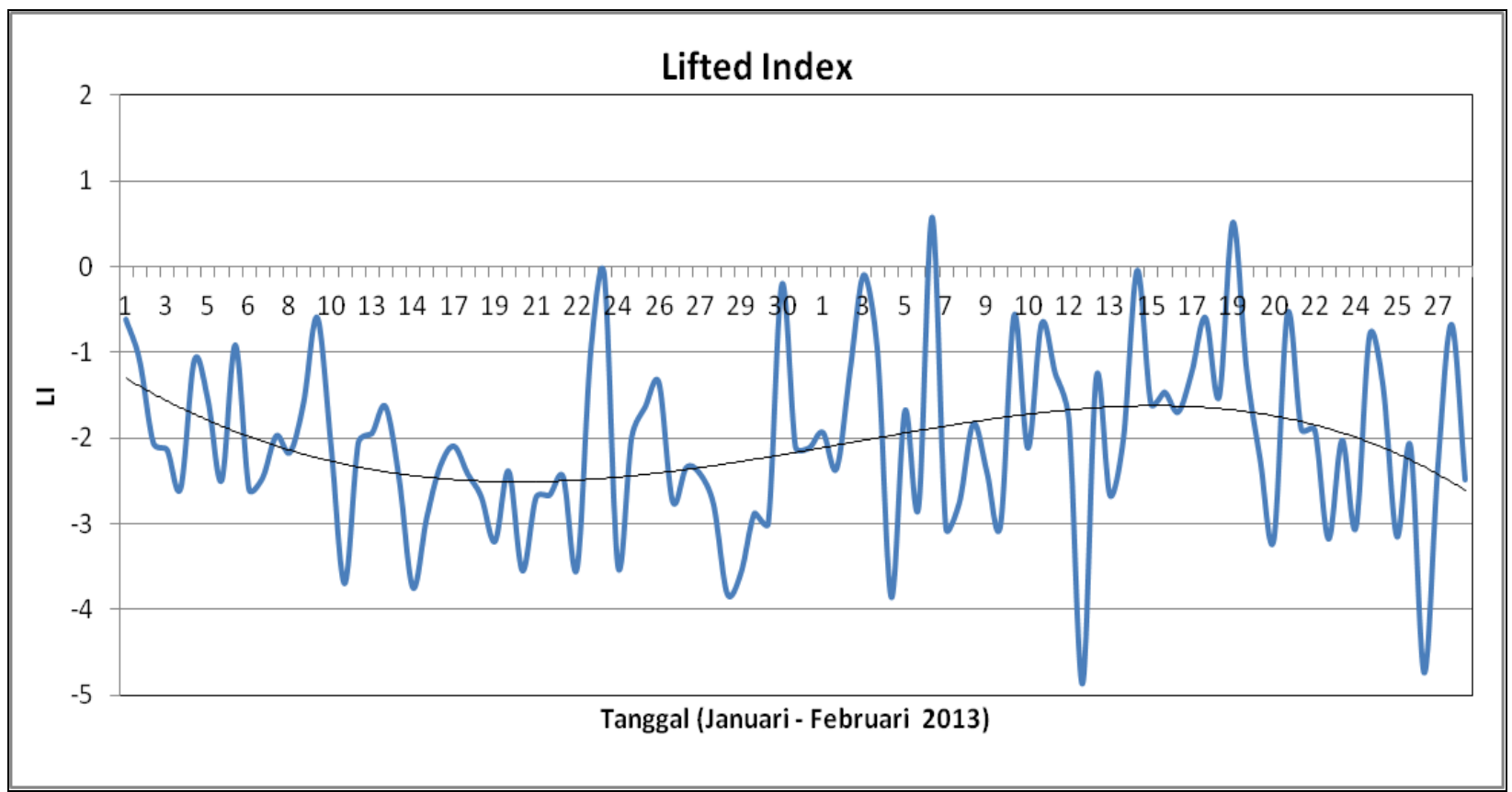

Gambar 7. Lifted Indeks

Pada hari-hari kejadian banjir tanggal 6 Februari nilai LI berfluktuatif, hal ini menunjukkan bahwa kondisi atmosfer pada saat itu kadang dipengaruhi oleh kondisi lokal (nilai LI negatif) kadang dipengaruhi oleh kondisi global (nilai LI disekitar nol). Nilai LI disekitar nol sampai positif mengindikasikan kondisi atmosfer yang relatif stabil, sehingga apabila terjadi hujan merupakan hujan dari awan tipe stratiform.

Convective Available Potential Energy. Besarnya energi angkat yang digambarkan oleh nilai CAPE selama bulan Januari dan Februari 2013 disajikan dalam Gambar 8, sumbu mendatar di bawah adalah nilai CAPE (warna merah muda) dan CIN / Convective Inhibition (warna biru) sedangkan sumbu mendatar di atas adalah nilai presipitasi wilayah Jakarta. CAPE menggambarkan besarnya energi angkat (buoyance) dalam proses pertumbuhan awan konvektif, sedangkan CIN adalah anti-CAPE (CAPE negatif) di lapisan troposfer bawah. Ini adalah kondisi parcel udara yang terangkat ke boundary layer akan turun kembali. Semakin tebal lapisan CIN maka akan semakin sulit pengangkatan secara konvektif. Sejak tanggal 11 sampai 21 Januari 2013 nilai CAPE cukup besar mencapai $1000 \mathrm{~J} / \mathrm{kg}$, nilai energi sebesar ini member peluang besar untuk pertumbuhan awan konvektif dan terbentuknya badai (thunderstorm). Pada awal Februari 2013 nilai CAPE umumnya disekitar $400 \mathrm{~J} / \mathrm{kg}$ yang mengindikasikan energi angkat tidak begitu tinggi. Meskipun energi angkat yang tidak terlalu besar tetapi peluang pertumbuhan awannya masih cukup besar karena didukung dengan supplay uap air yang melimpah.

Dari analisis nilai LI dan CAPE untuk kedua kejadian bajir tersebut dapat diketahui bahwa pengaruh lokal sangat kuat (disamping faktor sinoptiknya) pada kejadian banjir tanggal 17 Januari 2013, sehingga kemunculan awan Cumulonimbus (Cu) dan thunderstorm cukup banyak. Kemunculan awan-awan konvektif Cumulonimbus mengakibatkan kejadian hujan dengan intensitas yang sangat tinggi. Sedangkan untuk kejadian hujan tanggal 6 Februari 2013 lebih didominasi oleh faktor global yang menghasilkan curah hujan dengan durasi lama. 


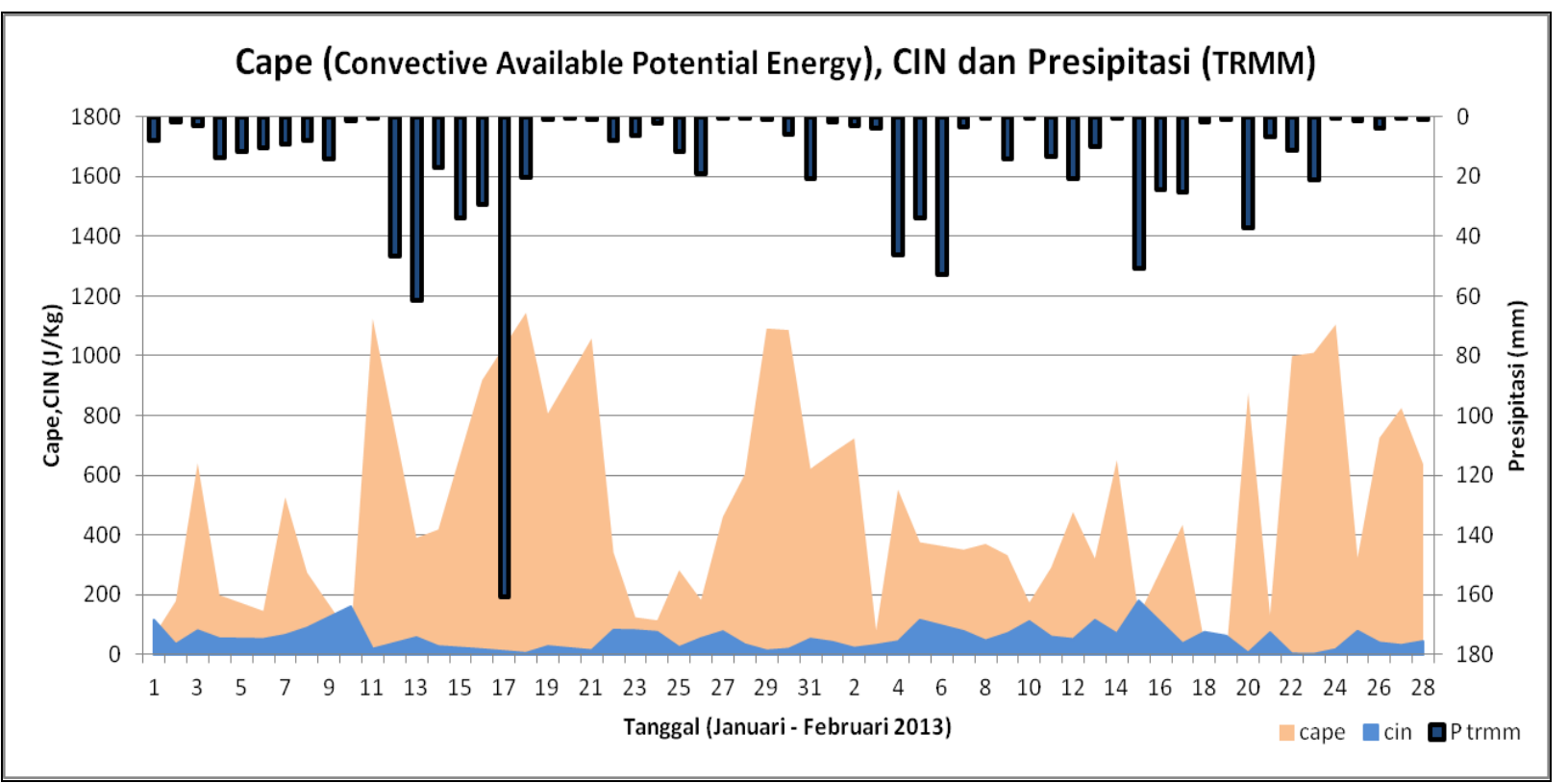

Gambar 8. CAPE (Convective Available Potential Energy), CIN (Convective Inhibition) dan nilai presipitasi bulan Januari-Februari 2013

\subsection{Profil Angin Bulan Januari - Februari 2013}

Hasil pengolahan arah dan kecepatan angin diperoleh komponen zonal dan komponen meridional. Untuk wilayah Jakarta komponen zonal positif (baratan) merepresentasikan angin yang membawa udara basah (monsoon asia) sedangkan komponen zonal negatif (timuran) merepresentasikan angin membawa massa udara kering (monsoon Australia). Hasilnya disajikan dalam Gambar 9.
Dari gambar profil angin tersebut terlihat bahwa selama bulan januari 2013 di wilayah Jakarta didominasi oleh komponen zonal (+) (baratan) sampai lapisan tinggi. Komponen baratan pada periode tersebut merepresentasikan monsoon India yang membawa cukup banyak uap air dari Laut Cina Selatan. Pada awal sampai pertengahan bulan Februari 2013 komponen baratan terdeteksi hanya sampai ketinggian 1500 meter (sekitar 5000 feet), pada lapisan di atasnya bertiup komponen timuran secara kuat.

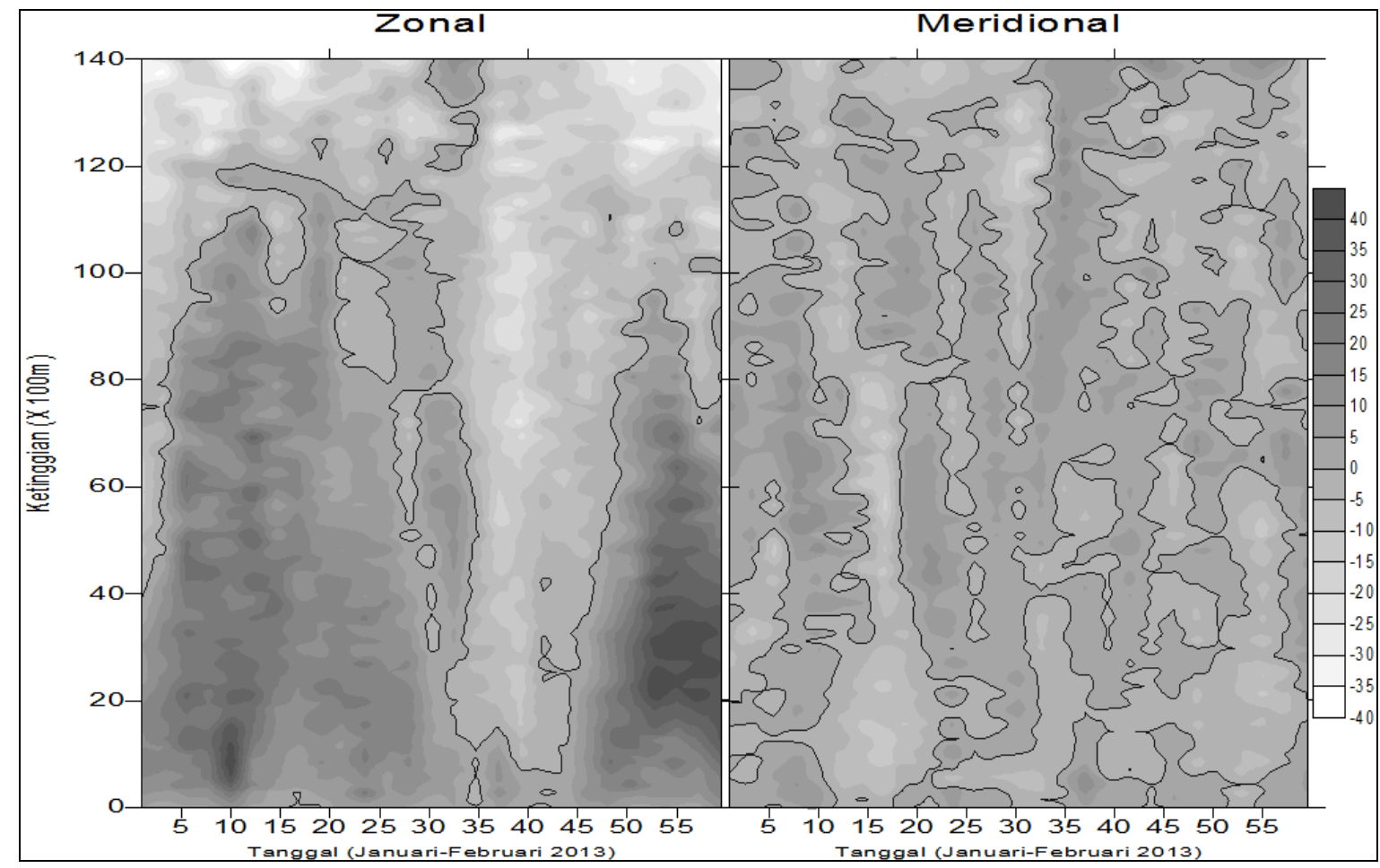


Gambar 9. Komponen angin zonal dan meridional bulan Januari-Februari 2013

\section{KESIMPULAN DAN SARAN \\ 4.1 Kesimpulan}

Puncak kejadian banjir Jakarta musim hujan tahun 2013 terjadi pada tanggal 17 Januari 2013 yang disebabkan faktor lokal yang sangat kuat ditambah dengan faktor global yang mendukung, sementara pada kejadian banjir tanggal 6 Februari 2013 faktor lokalnya tidak begitu kuat sehingga diduga faktor globalnya lebih dominan.

Untuk wilayah Jakarta terdapat indikasi bahwa pada musim hujan, intensitas curah hujan wilayah Jakarta yang melebihi $40 \mathrm{~mm} /$ hari selama lebih dari empat hari berturut-turut mempunyai potensi besar menimbulkan genangan (banjir).

\subsection{Saran}

Perlunya kewaspadaan yang lebih tinggi lagi dengan meningkatkan antisipasi pada saat terjadi curah hujan dengan intensitas tinggi selama empat hari berturut-turut.

\section{Daftar Pustaka}

AntaraNews, 2013, Kerugian akibat banjir Jakarta diperkirakan Rp20 triliun, http:// http://www.antaranews.com/berita/354430/ke rugian-akibat-banjir-jakarta-diperkirakan-rp20triliun.

Center for Ocean-Land-Atmosphere Studies (COLA), Grid Analysis and Display System (GrADS); http://www.iges.org/grads/

Glickman, Todd S., 2000, Glossary of Meteorology (Hardback), American Meteorological Society, Cambridge, Massachus-setts.

Irribane and Godson, 1981, Athmospheric Thermodynamics, Volume 6, 2nd edition, D. Reidel, U.S.A.

Japan Aerospace Exploration Agency Earth Observation Research Center, 2013, User's Guide for Global Rainfall Map in Near-RealTim e by JAXA Global Rainfall Watch (GSMaP_NRT), Version 2.4.

Rogers, R. R., 1979. A Short Course in Cloud Physics, $2^{\text {nd }}$ Edition, Pergamon Press.

Montheith, J. L. 1977. Climate. Academic Press. Inc. New York 